Fundamentals of Botany Series

\title{
Nonseed Plants: Second Edition Form and Function
}




\section{Fundamentals of Botany Series}

edited by

William A. Jensen

University of California, Berkeley

Leroy G. Kavaljian

Sacramento State College
The Plant Cell

William A. Jensen, University of

California, Berkeley

Reproduction, Heredity, and Sexuality Stanton A. Cook, University of Oregon

Nonseed Plants: Form and Function

William T. Doyle, University of California, Santa Cruz

Vascular Plants: Form and Function

Frank B. Salisbury, Utah State University, and Robert V. Parke,

Colorado State University

Plants, Man, and the Ecosystem

W. D. Billings, Duke University

Plants and Civilization

Herbert G. Baker, University of

California, Berkeley
Plant Variation and Classification

C. Ritchie Bell, University of North Carolina

Evolution and Plants of the Past Harlan P. Banks, Cornell University 


\section{Nonseed Plants: Second Edition Form and Function}

William T. Doyle

University of California, Santa Cruz 
Published by

THE MACMILLAN PRESS LTD

London and Basingstoke

Associated companies in

New York Dublin Melbourne

Johannesburg and Madras

SBN 333059980
ISBN 978-1-349-00414-0 ISBN 978-1-349-00412-6 (eBook) DOI 10.1007/978-1-349-00412-6

(C) 1964, 1970 by Wadsworth Publishing Company, Inc., Belmont, California.

Reprint of the original edition 1970

All rights reserved. No part of this publication may be reproduced or transmitted, in any form or by any means, without permission.

First published in the United States, 1964

First published in the United Kingdom 1964

First edition 1964

Reprinted 1964

Second edition 1973

The paperback edition of this book is sold subject to the condition that it shall not, by way of trade or otherwise, be lent, resold, hired out or otherwise circulated without the publisher's prior consent, in any form of binding or cover other than that in which it is published and without a similar condition including this condition being imposed on the subsequent purchaser. 


\section{Preface}

Nonseed Plants: Form and Function provides an essential core of information for the beginning student who meets lower plants for the first time. All chapters have been revised in the light of our greatly increased knowledge of the nonseed plant in the last seven years. The role of the electron microscope in expanding our vision of their morphology and ultrastructure is reflected in the electron micrographs included in the illustrations. Data from biochemistry, physiology, and developmental studies is included in the discussion of the organisms and in establishing their evolutionary relationships. Although new material has been added to all chapters, there has been extensive reworking of those chapters (viruses and bacteria, fungi, slime molds, bluegreen algae, and euglenoids) where the research has been most intensive. The features which proved particularly useful in the first edition, such as the summary of the evolutionary relationships at the end of the chapters, have been retained and refined. Furthermore, new illustrations have been added throughout, including some excellent electron micrographs, and virtually all line drawings have been elegantly redone.

Because the coverage of this second edition has been extended to include the nonseed-producing vascular plants, a change in title was necessitated. At this time, I would like to gratefully acknowledge the encouragement and constructive criticism of the many teachers and students who have used the first edition. I would like especially to thank Dr. Elizabeth Gantt, who read and made many valuable suggestions on the manuscript of the first edition. I also wish to express my gratitude to all who have kindly allowed me to use their illustrations in this book. Specific acknowledgment is found in the picture captions. 


\section{Series \\ Foreword}

Because of the immensity and complexity of the field of botany, the great diversity of plants, and the many methods of plant study, the problem of how to present to the student the highlights of botanical knowledge gained over centuries is not easy to solve. The authors and editors of the volumes in this series believe that an understanding of plants - their parts, their activities, and their relationship to man - is of fundamental importance in appreciating the significance of life. To stress this concept, the form and function of plants, tissues, and cells are treated together. At all levels of organization, in each volume, information gathered by morphologists, physiologists, cytologists, taxonomists, geneticists, biochemists, and ecologists is combined.

Thus, in the volume on The Plant Cell by William A. Jensen, the structure and function of the various cell parts are discussed together - for example, mitochondria and respiration, photosynthesis and chloroplasts. The volume by Stanton A. Cook, Reproduction, Heredity, and Sexuality, combines the principles of genetics with the means of reproduction in the various plant groups. The present volume, Nonseed Plants: Form and Function, by William T. Doyle, and Vascular Plants: Form and Function, by Frank B. Salisbury and Robert V. Parke, cover the major plant groups and discuss the plants in terms of morphology, physiology, and biochemistry. The relation of plants, particularly vascular plants, to their environment, to each other, and to man is covered in Plants, Man, and the Ecosystem by W. D. Billings. The form and distribution of plants of the past and their relation to the concepts of evolution are considered by Harlan Banks in Evolution and Plants of the Past. Herbert G. Baker, in Plants and Civilization, 
discusses the importance of plants to man's social and economic development and the equally important consideration of man's role in the modification and distribution of plants.

In a series such as this, the editors are faced with the task of dividing a broad field into areas that can be presented in a meaningful way by the authors. There must be logic in the entire scheme, with few gaps and a minimum of overlap. Yet an instructor may not want to use the series of volumes in the sequence and manner preferred by the editors. Consequently, each volume must be usable alone and also in any sequence with the others. To achieve such a high degree of versatility is difficult, but we believe the series exhibits these features.

A concerted effort has been made by the authors and editors to maintain a consistent level of presentation. However, each author has been encouraged to approach his subject in his own way and to write in his own style in order to provide variety and to exploit the uniqueness of the individual author's viewpoint. Finally, while presenting the principles of botany we have tried to communicate the excitement of recent developments as well as the joy that comes with the extension of knowledge in any field. 


\section{Contents}

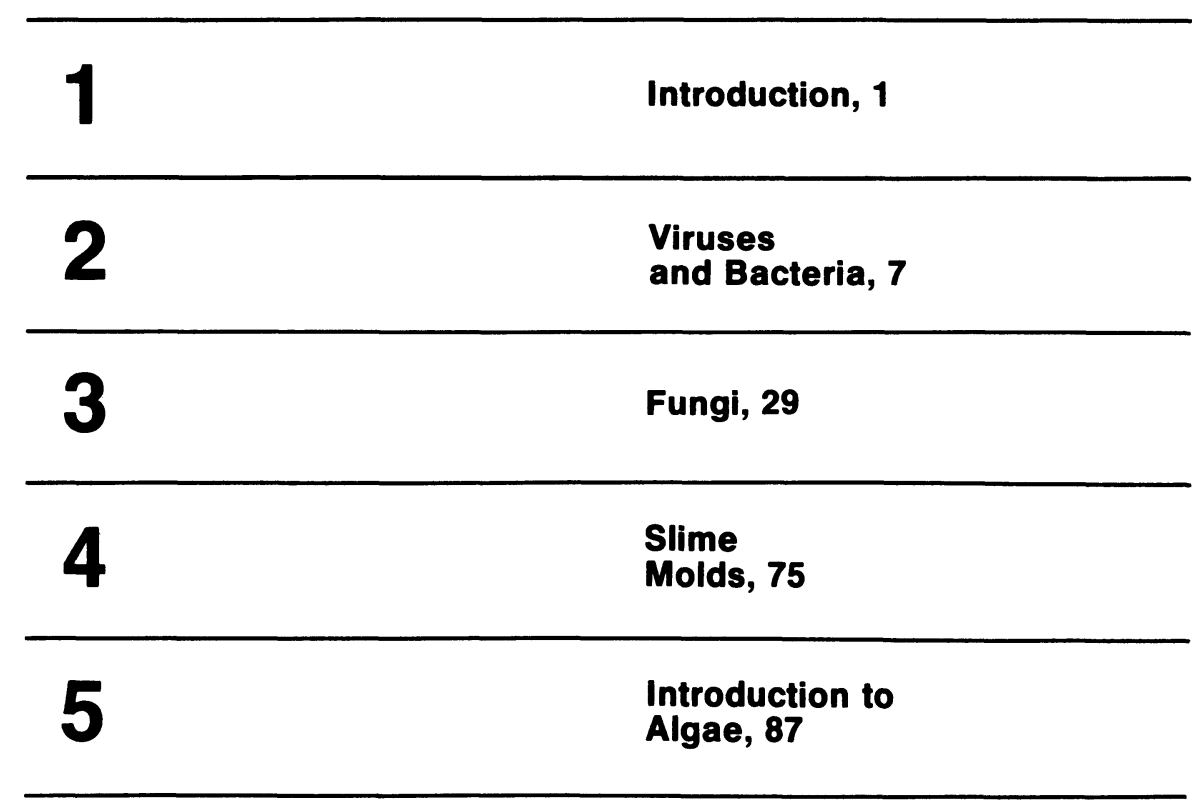




$6 \quad \begin{aligned} & \text { Blue-Green } \\ & \text { Algae, } 99\end{aligned}$

Algae, 99

7 Red

Algae, 109

8 Golden Algae

and Diatoms, 117

Brown

Algae, 127

10

Euglenoids, 139

11

Green

Algae, 149 
Bryophytes, 169

Ferns and

Fern Allies, 193

Appendix, 217

Glossary, 221

Suggestions

for Further Reading, 228

Index, 231 